Tomasz Homa

ORCID: 0000-0002-4430-2591

Jesuit University Ignatianum in Krakow

tomasz.homa@ignatianum.edu.pl

DOI: $10.35765 /$ pk.2019.2603.08

\title{
Joy and Sadness in Spiritual Life According to St. Ignatius of Loyola. A Hermeneutic Study (Part I)
}

\section{ABSTRACT}

The goal of this study is an interpretative attempt at human emotionality, and to be more specific, its emotional form of expression in various experiences of joy and sadness, in the light of the principles underlying one of the schools of Christian spirituality, i.e. the one proposed by Ignatius of Loyola (1491-1556). According to this movement of spiritual life, which draws on the centuries-old biblical experience and Christian conception of the emotional dimension of our lives, and which also enriches it with experiences and reflections of Ignatius himself, our emotionality - not infrequently experienced as a peculiar and often incomprehensible "babble" - may in fact be construed as equally emotional and lucid "speech." Such "speech" becomes comprehensible the moment we are able to properly "read," that is recognize and understand the emotional experiences that we are exposed to in this sphere.

KEY WORDS: discernment of spirits, emotionality, spiritual joy consolation, spiritual sadness - desolation, spiritual life 
STRESZCZENIE

\section{Radośc $i$ smutek $w$ życiu duchowym wedtug Ignacego Loyoli. Studium hermeneutyczne (część I)}

Celem tego studium jest próba interpretacji ludzkiej emocjonalności w jej uczuciowej formie wyrazu w postaci przeżyć radości i smutku, w świetle założeń jednej ze szkół duchowości chrześcijańskiej, mianowicie tej zaproponowanej przez Ignacego Loyolę (1491-1556). Według tego nurtu życia duchowego, zarówno czerpiącego z wielowiekowego doświadczenia biblijnego i chrześcijańskiego rozumienia emocjonalno-uczuciowego wymiaru naszego życia, jak i wniesionych do niego doświadczeń i przemyśleń poczynionych przez samego Ignacego, nasza emocjonalność doświadczana niejednokrotnie jako swoisty i często niezrozumiały „gwar” może, w rzeczywistości, stanowić równie emocjonalną, czytelną „mowę”. „Mowę”, która staje się zrozumiałą z chwilą, gdy potrafimy właściwie „rozczytać”, czyli rozpoznać i zrozumieć, doświadczane przez nas w tej sferze emocjonalno-uczuciowe przeżycia.

\section{SŁOWA KLUCZE: rozeznanie duchowe, duchowa radość - pocieszenie, duchowy smutek - strapienie, uczucia, życie duchowe}

A lot has been written about the world of human emotionality. Also, a lot of thought, including philosophical, theologico-spiritual and psychological thought, has been given to its various forms materializing in experiences of both joy and sadness sensu largo.

Even though it is not my intention to present a review of positions and theories concerned with the question at hand, some references to it will be necessary. The idea behind this reflection is an interpretative attempt at human emotionality, and to be more specific, its emotional form of expression in various experiences of joy and sadness, in the light of the principles underlying one of the schools of Christian spirituality, i.e. the one proposed by Ignatius of Loyola (1491-1556), a co-founder of the Society of Jesus, also known as the Jesuit Order.

According to this movement of spiritual life, which draws on the centuries-old biblical experience and Christian conception of the emotional dimension of our lives, and which also enriches it with experiences and reflections of Ignatius himself, our emotionality - not infrequently experienced as a peculiar and often incomprehensible "babble" - may in fact 
be construed as equally emotional and lucid "speech." Such "speech" becomes comprehensible the moment we are able to properly "read," that is recognize and understand the emotional experiences that we are exposed to in this sphere.

An attempt at this kind of "readings" of emotional states, as a case study of its own kind, will be addressed in the second part of this reflection.

\section{Part I}

\section{An experience of inner movements and attendant emotional states}

In The Autobiography of St. Ignatius, penned in 1553-1555 by Father Gonçalves da Câmara, Ignatius of Loyola, who was then the first Superior General of the Jesuit Order, presents a succinct account of some existential experience from the period of his convalescence in 1521-1522, which was to become his key to understanding human emotionality in a Christian's spiritual life. The broad context of this experience is outlined in paragraph No. 7 in the first chapter of The Autobiography. Its core and the meaning ascribed to it by Ignatius is contained in paragraphs 9-10, which I quote together with paragraph 7 . They read as follows:

7. As Ignatius had a love for fiction, when he found himself out of danger he asked for some romances to pass away the time. In that house there was no book of the kind. They gave him, instead, "The Life of Christ," by Rudolph, the Carthusian, and another book called the "Flowers of the Saints," both in Spanish. By frequent reading of these books he began to get some love for spiritual things. This reading led his mind to meditate on holy things, yet sometimes it wandered to thoughts which he had been accustomed to dwell upon before. ...

9. ... This succession of thoughts occupied him for a long while, those about God alternating with those about the world. But in these thoughts there was this difference.

When he thought of worldly things it gave him great pleasure, but afterward he found himself dry and sad. But when he thought of journeying to Jerusalem, and of living only on herbs, and practising austerities, he found pleasure not only while thinking of them, but also when he had ceased.

10. This difference he did not notice or value, until one day the eyes of his soul were opened and he began to inquire the reason of the difference. 
He learned by experience that one train of thought left him sad, the other joyful.

... When gradually he recognized the different spirits by which he was moved, one, the spirit of God, the other, the devil. ${ }^{1}$

\section{The role of joy and sadness as spiritual consolations and desolations according to The Spiritual Exercises}

The experience of emotional states of joy and sadness, appearing in their nuanced forms in spiritual life, was to be later on explored and elucidated from the existential and theological perspective in The Spiritual Exercises, which Ignatius himself edited. He expounds their sense in the first of the twenty "Annotations" preceding the Exercises. As he writes, the "Annotations" serve "to give some understanding of the spiritual exercises:

by this name of Spiritual Exercises is meant every way of examining one's conscience, of meditating, of contemplating, of praying vocally and mentally, and of performing other spiritual actions, as will be said later. For as strolling, walking and running are bodily exercises, so every way of preparing and disposing the soul to rid itself of all the disordered tendencies, and, after it is rid, to seek and find the Divine Will as to the management of one's life for the salvation of the soul, is called a Spiritual Exercise. ${ }^{2}$

As regards the emotional states experienced as joy or sadness, which by Ignatius are also termed consolations ${ }^{3}$ and desolations ${ }^{4}$ respectively, these

1 The Autobiography of St. Ignatius, ed. J.F.X. O’Connor, Benziger Brothers, New York 1900, pp. 7-8. This work will be hereafter quoted as The Autobiography.

2 The Spiritual Exercises of St. Ignatius of Loyola, trans. Father Elder Mullan, S.J., P.J. Kenedy \& Sons, new York 1914, "Annotations," First Annotation. This work will be hereafter quoted as The Spiritual Exercises.

3 Ignatius of Loyola defines "consolation" in "Rules of discernment of spirits," as follows: "I call it consolation when some interior movement in the soul is caused, through which the soul comes to be inflamed with love of its Creator and Lord; and when it can in consequence love no created thing on the face of the earth in itself, but in the Creator of them all. Likewise, when it sheds tears that move to love of its Lord, whether out of sorrow for one's sins, or for the Passion of Christ our Lord, or because of other things directly connected with His service and praise. Finally, I call consolation every increase of hope, faith and charity, and all interior joy which calls and attracts to heavenly things and to the salvation of one's soul, quieting it and giving it peace in its Creator and Lord” (The Spiritual Exercises, "Third Rule," The third: of Spiritual Consolation).

4 According to the "Fourth Rule," of spiritual desolation, which also belongs to the "Rules of discernment of spirits," Ignatius of Loyola notes: "I call desolation all the contrary of the third rule 
states, in The Spiritual Exercises, constitute an extremely important manner of existential-spiritual "insight" into inner experiences of he who is performing the Exercises. ${ }^{5}$ Ignatius attached a lot of weight to this kind of "insight," which came to be evidenced by his recommendations in this respect, contained in the Sixth and Seventeenth Annotations, where we read the following:

Sixth Annotation. When he who is giving the Exercises sees that no spiritual movements, such as consolations or desolations, come to the soul of him who is exercising himself, and that he is not moved by different spirits, he ought to inquire carefully of him about the Exercises, whether he does them at their appointed times, and how... ${ }^{6}$

Seventeenth Annotation. It is very helpful that he who is giving the Exercises ... should be faithfully informed of the various movements and thoughts which the different spirits put in him. For, according as is more or less useful for him, he can give him some spiritual Exercises suited and adapted to the need of such a soul so acted upon. ${ }^{7}$

What is the rationale behind the import of these emotional states, and why does Ignatius give so much attention to them in both The Spiritual Exercises, which are a special school "of preparing and disposing the soul to rid itself of all the disordered tendencies, and, after it is rid, to seek and find the Divine Will as to the management of one's life for the salvation of the soul," ${ }^{8}$ and outside the time of the Spiritual Exercises, in everyday spiritual life, as he recommends, in both the cases, their careful analysis?

The answer to these questions can be furnished by his conception of man as well as the meaning and purpose of human life, the essence

["Of spiritual consolation”], such as darkness of soul, disturbance in it, movement to things low and earthly, the unquiet of different agitations and temptations, moving to want of confidence, without hope, without love, when one finds oneself all lazy, tepid, sad, and as if separated from his Creator and Lord. Because, as consolation is contrary to desolation, in the same way the thoughts which come from consolation are contrary to the thoughts which come from desolation" (The Spiritual Exercises, "Fourth Rule," The fourth: of Spiritual Desolation).

5 The "consolations" and „desolations" that Ignatius writes about "are not mere emotional states and so they should not be construed through their purely psychological sense. Ignatius imparts them a more profound, spiritual sense, discerning their causes in actions taken by good spirits (God and angels) or evil spirits" (Św. Ignacy Loyola, Opowieść Pielgrzyma. Autobiografia, trans. and ed. M. Bednarz, SJ, 4th extended edition, WAM Publishing House, Kraków 2018, endnote No. 28, pp. 128-129. This work will be hereafter quoted as Opowieść pielgrzyma).

6 The Spiritual Exercises, "Annotations," Sixth Annotation.

7 The Spiritual Exercises, "Annotations," Seventeenth Annotation.

8 The Spiritual Exercises, "Annotations," First Annotation. 
of which are not defined by theoretical and speculative deliberations engaged in by the then-predominant philosophical and theological doctrines, but by his personal experiences and reflections of both an existential and religious character. The exploration of these experiences through the spiritual and sapiential prism he would only ascribe to God, who "was at work." ${ }^{9}$

To wit, on the one hand, the existential and spiritual experiences and reflections that constitute a continuation and advancement of the understanding of this special experience from the period of convalescence at the family home, which firstly made him realise that "one train of thought left him sad, the other joyful," ${ }^{10}$ and, secondly, came to underlie the process of discovering and learning, in his opinion, their real and supernatural sources, that is "different spirits by which he was moved, one, the spirit of God, the other, the devil." 11

On the other hand, the existential, religious and mystical experiences and reflections concerned with the meaning and purpose of human life, which Ignatius engaged in as a Pilgrim, particularly in Manresa, and which he synthetically captured in the Principle and Foundation of The Spiritual Exercises, that is the Foundation of the Exercises, in the following words: "man is created to praise, reverence, and serve God our Lord, and by this means to save his soul." ${ }^{12}$ And therefore in the phrasing that is "a fruit of the mystical cognition of the Triune God and the act of creation," ${ }^{13}$ and

9 The Autobiography, p. 8.

10 Ibidem.

11 Ibidem.

12 The Spiritual Exercises, Principle and Foundation [Foundation of Exercises]. As Mieczysław Bednarz notes, while it is disputable whether the wording of the Foundation was influenced by Erasmus of Rotterdam, or Alfonso of Madrid, or Peter Lombard, "it is a fact that in its essence, in its fundamental train of thought, the Foundation was conceived in Manresa, even though the wording was formed probably later on" (Św. Ignacy Loyola, Pisma Wybrane. Komentarze II [Selected Writings. Commentaries II], ed. M. Bednarz, SJ, co-ed. A. Bober, SJ and R. Skórka, SJ, Wydawnictwo Apostolstwa Modlitwy, Kraków 1968, p. 392).

13 Św. Ignacy Loyola, Pisma wybrane. Komentarze II, op. cit., p. 392. À propos this "At first glance we might feel inclined to recognize the Foundation as a philosophical conclusion incontrovertibly following from the once-and-for-all accepted truth about God the Creator and the ultimate Purpose of all things. But that is not the case. Ignatius ..., a straightforward and uneducated man with an extremely practical and action-oriented attitude, and exhausted by exaggerated penance and spiritual torments, was by no means predisposed towards philosophy. As an expression of his attitude to God the Creator and to divine creatures, the Foundation is a fruit of the mystical cognition of the Triune God and the act of creation. The seemingly cold, calm and concise wording hides the smouldering ardour of an experience incomparably higher and deeper than any philosophical investigations" (ibidem). The cited "ardour of an experience incomparably higher and deeper than any philosophical investigations" is "mystical seeing and experiencing God in Manresa, [which] was not for Ignatius a kind of aesthetic contemplation, 
hence deriving its import as the most essential principle, or a foundation for a well-organised human life, that is a life lived so that "I shall find myself on the Day of Judgment ... in entire pleasure and joy." 14

\section{Self-knowledge}

Under the influence of this kind of existential and mystical experiences and reflections, cognition and understanding of himself and every man crystallize in Ignatius; today we would call such cognition and understanding holistic.

It is existential and spiritual cognition, which thanks to these experiences and observations merges all dimensions of human life, that is judiciousness, volition and emotionality into a harmonious, constitutively varied, corporeal-spiritual whole and unity.

It is also a spiritual and religious cognition, the extremely important foundations of which constitute Ignatius' closely interrelated experiences from the time of his convalescence, namely that "one train of thought left him sad, the other joyful," 15 and gradual explanations of the real causes of these thoughts and attendant emotional states, to wit "the different spirits."

He contained these explanations, of such great importance and usefulness, in The Spiritual Exercises - in the section on General Examen of Conscience, which he was very particular about as the most basic instrument of attentive spiritual life - noting for the benefit of those willing to use the Spiritual Exercises the following:

I presuppose that there are three kinds of thoughts in me: that is, one my own, which springs from my mere liberty and will; and two others, which come from without, one from the good spirit, and the other from the bad. ${ }^{16}$

Thus, the spiritual and religious cognition which was born in him slowly leads him through his manifold thoughts, and spiritual movements resulting therefrom, not only to the discovery of spirits acting in him, but

quiet intuition or awe. To him God was not merely Deus magnificus - great and mighty God, but distant and alien God. That was his God, his Father, found to be full of Divine love for man, for creation, full of Divine redemptive will desiring to attract all His creatures. God - love that offers itself generously and that attracts everything" (ibidem, p. 393).

14 The Spiritual Exercises. The second way to make a good any sound election, "Fourth Rule," The fourth.

15 The Autobiography, p. 8.

16 The Spiritual Exercises, "General Examen of Conscience." 
also to the recognition of the difference between spirits "by which he was moved, one, the spirit of God, the other, the devil," ${ }^{17}$ as well as proper action for each of them.

Consequently, they lead him also to the discovery of the universal in its meaning principle according to which in every man both the good spirit (God and angels) and the evil spirit act, or can act, in their own peculiar manners and according to their own intention.

The former one - the good spirit - acts upon man by inspiring thoughts, desires and/or inner movements in the form of states of joy or sadness to move him to undertake and/or fulfil the meaning and purpose of his life on manifold paths of Divine love, which Ignatius addresses in the abovementioned Principle and Foundation, which he introduces as the opening of the "First Week" of the Spiritual Exercises.

The latter one - the evil spirit - acts upon man by dissuading him from that which comes within the compass of the good spirit's activity, inspiring in him thoughts, desires and/or spiritual movements that discourage him from seeking God, living in His presence, or encourage him to persist in a state of life contrary to the one presented in the Principle and Foundation of the Exercises, or to confirm him in such a state.

Similarly, this kind of Ignatius' experiences, originating from his personal experience gained in the period of convalescence, on the basis of which "when he began the Spiritual Exercises, he was enlightened ... about the discernment of spirits," ${ }^{18}$ leads him to the discovery that such actions by various spirits can be found both in every dimension of human life, in a mode peculiar to each one of these dimensions - in a rational mode through thoughts, in a volitive mode through desires and in an emotional mode through "spiritual movements, such as consolations or desolations," 19 or in some peculiar rational-volitive-emotional configuration of these.

And finally, on account of this, that the everyman manifests himself in his existence as the one who - in all his complex corporeal-spiritual unity under the rule of the three powers of the soul, that is intellect, will

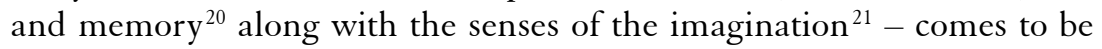

17 The Autobiography, p. 8.

18 The Autobiography, p. 8.

19 The Spiritual Exercises, "Annotations," Sixth Annotation.

20 Cf. The Spiritual Exercises, "First Exercise." "It is a meditation with the three powers," which Ignatius describes in more detail in the First Point of the Meditation, recommending that the memory be used in order to recall the object of meditation, and then the intellect to consider, and finally the will, "wanting to recall and understand all this" (ibidem).

21 Ignatius accepts the existence of the five senses of the imagination and recommends using them both in meditation ("Fifth Exercise" - It is a meditation on hell) and in contemplation ("Fifth 
tasked with a double role. Namely, being a "field," or an "arena" - which is of considerable bearing for him - of a spiritual fight over himself, a place of actions oriented at him and undertaken by both the good spirit and the evil spirit, as well as being one who in such struggles cannot be a passive or neutral observer, but must freely choose either of the sides as its active adherent.

\section{Rules of discernment of spirits}

The experience of spiritual movements in the form of states of joy or sadness experienced by Ignatius under the influence of some thoughts, as well as his careful examination of these movements, concluded with the abovementioned statement whereby "there are three kinds of thoughts in me: that is, one my own, which springs from my mere liberty and will; and two others, which come from without, one from the good spirit, and the other from the bad," 22 as well as the discovery that thoughts coming from without are not neutral, but through their agency and in no accidental manner both the good spirit and the evil spirit, inspiring in him states of spiritual consolation or desolation, and therefore that emotional states may have spiritual significance as "clear traces" of supernatural interventions, namely of action undertaken in man by different spirits, came to be more profoundly explored in his "Rules of discernment of spirits," used "for perceiving and knowing in some manner the different movements which are caused in the soul: the good, to receive them, and the bad to reject them." 23

As I do not intend to go into detailed analysis of these rules, as this would exceed the compass of the present study, and as I do not comment on them for the time being, let me just quote only those of the rules which feature emotionality in its spiritual (inner) form of joy and/or sadness.

I.

First Rule. The first Rule: In the persons who go from mortal sin to mortal sin, the enemy is commonly used to propose to them apparent pleasures, making them imagine sensual delights and pleasures in order to

Contemplation," of the Incarnation and of the Nativity). As for using this kind of senses, he advises that while pondering the object of meditation or contemplation the exercitant "see ... with the sight of the imagination...," "hear with the hearing [of the imagination]...," "smell and taste with the smell and the taste [of the imagination]...," "touch with the touch [of the imagination]..." (The Spiritual Exercises, "Fifth Exercise").

22 The Spiritual Exercises, "General Examen of Conscience."

23 The Spiritual Exercises, "Rules for perceiving and knowing in some manner ...." 
hold them more and make them grow in their vices and sins. In these persons the good spirit uses the opposite method, pricking them and biting their consciences through the process of reason.

Second Rule. The second: In the persons who are going on intensely cleansing their sins and rising from good to better in the service of God our Lord, it is the method contrary to that in the first Rule, for then it is the way of the evil spirit to bite, sadden and put obstacles, disquieting with false reasons, that one may not go on; and it is proper to the good to give courage and strength, consolations, tears, inspirations and quiet, easing, and putting away all obstacles, that one may go on in well doing. ${ }^{24}$

\section{II.}

First Rule. The first: It is proper to God and to His Angels in their movements to give true spiritual gladness and joy, taking away all sadness and disturbance which the enemy brings on. of this latter it is proper to fight against the spiritual gladness and consolation, bringing apparent reasons, subtleties and continual fallacies.

Second Rule. The second: It belongs to God our Lord to give consolation to the soul without preceding cause, for it is the property of the Creator to enter, go out and cause movements in the soul, bringing it all into love of His Divine Majesty. I say without cause: without any previous sense or knowledge of any object through which such consolation would come, through one's acts of understanding and will.

Third Rule. The third: With cause, as well the good Angel as the bad can console the soul, for contrary ends: the good Angel for the profit of the soul, that it may grow and rise from good to better, and the evil Angel, for the contrary, and later on to draw it to his damnable intention and wickedness. ${ }^{25}$

\section{Existential experiences of joy and sadness and their function in spiritual life}

The previous analyses of both the experiences of spiritual states of joyconsolation and sadness-desolation in their diverse forms, which Ignatius addresses in his texts, namely: inner joy, gladness, consolation, contentment, quiet, comfort and all manner of growth of faith, hope and

24 Ibidem.

25 The Spiritual Exercises, "Rules for the same effect with greater discernment of spirits ...." 
love, as well as sadness, dissatisfaction, dryness, desolation, disquiet, disturbance, anguish, hopelessness and some kind of detachment, as well as his existential-spiritual-religious "readings" of these experiences may give the impression that the whole reality of emotionality thus expressed, or its significant forms belong only to the sphere of action of that which is supernatural, that is the good spirit or the evil spirit, thereby constituting some forms of expression of their influence on man. However, careful analysis of Ignatius' texts does not allow of such a conclusion.

In fact, Ignatius takes for granted the existence of the three kinds of thoughts in himself, making this differentiation a vital hint for spiritual life, and giving in his accounts of his spiritual experiences and reflections thereon a lot of attention to this kind of thoughts which in his opinion are of supernatural origin, namely coming from the good spirit or the evil spirit. Still, he does not omit this explicitly singled-out kind of thoughts which he defines as "my own [thought], which springs from my mere liberty and will," ${ }^{26}$ or the states of joy and/or sadness, aroused by these thoughts, and their relevance for well-ordered life. On the contrary, to these thoughts, which originate only in our human minds, and the various forms of states of joy and/or sadness resulting from them Ignatius ascribes importance equal to the one connected with thoughts coming from without.

It is rather safe to assume, without risking a mistake, that the reason justifying such an approach to his own thoughts is apparently his conception of man as a naturally rational and free being, and by extension one that thinks on his own, and that is created, as a creature rational and free in his thought and action, to praise, reverence, and serve God our Lord, and by this means to save his soul. ${ }^{27}$

Such an interpretation appears to be corroborated by the importance that Ignatius attaches to "bringing the intellect" not only on the truths of the faith, but also on all these matters that are to become objects of a Christian's sound and good election, including an election of a state of life, ${ }^{28}$ making judicious consideration one of the two basic principles of prudent conduct in spiritual life, and which can be termed principium rectae rationis, that is 'a principle of the right reason.'

Like thoughts from without, such thoughts "springing from my mere liberty and will" can cause being joyful as well as being sad, and that in at least two ways which Ignatius points to in his Exercises.

The first way, which I should call empathetic, or empathetic-participative, is when, for instance while considering some event in Jesus' life,

26 The Spiritual Exercises, "General Examen of Conscience."

27 Cf. The Spiritual Exercises, "Principle and Foundation," that is "Foundation of the Exercises."

28 Cf. The Spiritual Exercises, "Prelude for Making Election." 
Ignatius recommends arousing a desire for this kind of states in oneself, either in a spiritual form, like in the case of the desire "to arouse feeling and be glad at the great joy and gladness of Christ our Lord," ${ }^{29}$ or in a spiritual-sensual form, like in the case of a desire for physical tears of joy or tears of sadness, depending on the subject of given deliberation and intellectual consideration, or contemplation. In all situations like this, Ignatius means conscious forging of a spiritual-emotional bond of empathy, harmony, sharing experiences and desires with a view to deeper, fuller and more integral, corporeal-spiritual understanding and living the reality that constitutes an object of our thought and prayer.

The other of the above-mentioned ways, which can be characterised as effectual, or effectual-purposeful, takes place when such states occur as a result of our quiet consideration and decisions made on the basis of the consideration. And so, for instance in a situation within the context of making a good and sound choice in the so-called "quiet time," ${ }^{30}$ having carefully weighed the pros and cons that I can impartially visualise, "only looking at what we are created for." 31

In such situations, the states of joy and/or sadness that arise in a person appear to constitute - in Ignatius' opinion - a spiritual-emotional manifestation of the veracity and rightness of the decision made (effect), bearing in mind the meaning and purpose - recognised by the person thanks to their own cognitive powers of the intellect - of their own and every human existence (purposefulness of life), which Ignatius succinctly couched in the Principle and Foundation of spiritual life.

Explored by Ignatius, the complexity of the emotional states of joy and/ or sadness - with regard to both their natural and supernatural causes, and the variety of their functions in man's spiritual life depending on their origin as well as the existential-spiritual situation of the person experiencing them - constitutes an important heritage of Christian spiritual life. The heritage bearing the mark left by the history, religiousness and culture

29 The Spiritual Exercises, "The First Contemplation - How Christ our Lord appeared to our Lady," "Fourth Note." Ignatius recommends arousing in oneself such a desire while preparing to contemplate the events of the Resurrection of Jesus.

30 According to Ignatius, the "quiet time" is a man's spiritual state "when the soul is not acted on by various spirits, and uses its natural powers freely and tranquilly" (The Spiritual Exercises, "Three times for making, in any one of them, a sound and good election," "Third Time").

31 The Spiritual Exercises, "Prelude for Making Election," "First Point.” According to Ignatius' recommendation included in the introduction to the section on making a good and sound choice, "in every good election, as far as depends on us, the eye of our intention ought to be simple [cf. Matt 6:22 and Luke 11:34], only looking at what we are created for, namely, the praise of God our Lord and the salvation of our soul. And so I ought to choose whatever I do, that it may help me for the end for which I am created" (ibidem). 
of the era in which Ignatius lived. But also, the heritage the originality and import of which go beyond these determinants, becoming uninterruptedly, for almost five hundred years, a vital point of reference for those who want to understand and prudently develop their spiritual life.

Also, today we can inquire about the importance of this "reading" of human emotionality in the sphere of spiritual life, which was affected by Ignatius of Loyola, as well as about its significance for the 21 st-century man, in his quest for self-understanding and his efforts to make his life more successful. Reflections contained in the second part of this study attempt to answer these questions.

BIBLIOGRAPHY

Bednarz M., Bober A., Skórka R., Ignacy Loyola. Pisma wybrane. Komentarze II, Wydawnictwo Apostolstwa Modlitwy, Kraków 1968.

Loyola I., Ćwiczenia duchowne, Wydawnictwo WAM, Kraków 2002.

Loyola I., Opowieść Pielgrzyma. Autobiografia, Wydawnictwo WAM, Kraków 2018.

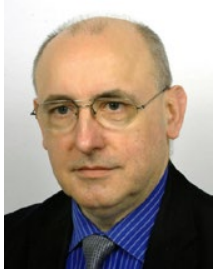

Tomasz Homa - jesuit, philosopher, professor at the Jesuit University Ignatianum in Krakow. In his research he deals with issues concerning social and political philosophy, existentialism, ethics and culture. Author of monographs on social and political philosophy: $W$ drodze do podmiotowości spoteczeństwa (Kraków 2002), Obywatelskość (Kraków 2013), Wspólnotowość (Kraków 2017) and co-author of Problemy wspótczesności a chrześcijanie. Zagadnienia etyczne i spoteczne do dyskusji dla mtodzieży i wychowawców (Kraków-Warszawa 2004). 
